\title{
Evaluation of Air Quality in Damietta Harbor Region
}

\author{
El Gammal, I Maie ${ }^{1}$, Alia A. Shakour ${ }^{2}$, Mahmoud S. Ibrahim¹, Omnya A. EI-Batrawy ${ }^{1}$, Walid A. Ali ${ }^{*}$
}

${ }^{1}$ Environmental Sciences Department, Faculty of Science, Damietta University, Egypt.

${ }^{2}$ Air pollution Department, National Research Centre, Cairo, Egypt.

Received: 9 July 2017 /Accepted: 2 Sept 2017

*Corresponding author: walid.env@ mopco-eg.com

\begin{abstract}
Ship emissions in port areas are dispersed mainly concerns sulfur dioxide $\left(\mathrm{SO}_{2}\right)$, nitrogen dioxide $\left(\mathrm{NO}_{2}\right)$, particulate matter, ... etc., in the atmosphere, affecting air quality and jeopardizing people's health and quality of life. This study aims to assess air quality of Damietta Harbor Region. Implementing continuous monitoring of major air pollutants $\left(\mathrm{NO}_{2}, \mathrm{SO}_{2}, \mathrm{CO}, \mathrm{O}_{3}\right.$ and $\left.\mathrm{PM}_{10}\right)$ were found in Damietta harbor by using Ambient Air Quality Monitoring Station (AAQMS) from January 2013 to December 2015. According to the obtained results, the annual mean levels of $\mathrm{NO}_{2}, \mathrm{SO}_{2}, \mathrm{CO}$ and $\mathrm{O}_{3}$ in Damietta Port Area in 2013, 2014 and 2015 were 29.92, 41.50 and 29.12 $\mu \mathrm{g} / \mathrm{m}^{3}$ of $\mathrm{NO}_{2}, 26.68,27.69$ and $24.83 \mu \mathrm{g} / \mathrm{m}^{3}$ of $\mathrm{SO}_{2}, 5.31,2.29$ and $6.23 \mathrm{mg} / \mathrm{m}^{3}$ of $\mathrm{CO}$ and 33.10 , 41.00 and $39.43 \mu \mathrm{g} / \mathrm{m}^{3}$ of $\mathrm{O}_{3}$, respectively. These results did not exceed the AQL as stipulated in the Egyptian Environmental Law 4/94 and its executive regulations $\left(80,60 \mu \mathrm{g} / \mathrm{m}^{3}\right)$ for $\mathrm{NO}_{2}$ and $\mathrm{SO}_{2}$, and $\left(10 \mathrm{mg} / \mathrm{m}^{3}\right.$ for $8 \mathrm{hrs}$.) for $\mathrm{CO}$, and $\left(120 \mu \mathrm{g} / \mathrm{m}^{3}\right.$ for $8 \mathrm{hrs}$.) for $\mathrm{O}_{3}$. Whereas, the annual mean levels of $\mathrm{PM}_{10}$ in Damietta Port Area were 83.56 and $72.32 \mu \mathrm{g} / \mathrm{m}^{3}$, in 2013 and 2015 respectively, found higher than AQL as stipulated in the Egyptian Environmental Law 4/94 and its executive regulations $\left(70 \mu \mathrm{g} / \mathrm{m}^{3}\right)$.
\end{abstract}

Keywords: Damietta Port Area, Ship emissions, Gases, $\mathrm{NO}_{2}, \mathrm{SO}_{2}, \mathrm{CO}, \mathrm{O}_{3}, \mathrm{PM}_{10}$.

\section{Introduction}

Human activities introduce numerous of chemical components into the atmospheric environments of urban areas through industrial wastes, traffic congestion and overcrowding in cities, etc. They contribute many environmental problems, such as photochemical smog and asthmatic disease. They influence also, on the composition of the atmosphere and on the atmospheric fallout (Matsumoto et al., 1980).

Air pollution due to ship emissions mainly concerns sulfur dioxide $\left(\mathrm{SO}_{2}\right)$, nitrogen dioxide $\left(\mathrm{NO}_{2}\right)$, and particulate matter. Ships at berth are also still responsible for air pollution in the port areas, mainly because of the use of engines for supplying auxiliary devices (Schembari et al., 2012; Adamo et al., 2014).

In recent years, environmental problems have become one of the most important topics on 
the agenda at international forums on politics, economics and science. Outdoor air pollution originates from a variety of sources including residential and industrial gases combustion, a burgeoning transport sector, chemical releases from industry, outdoor burning of agricultural waste, and dust from construction, roads and deserts. Exposure to outdoor air pollutants (mainly respirable particles, ozone, and nitrogen dioxide) has also been associated with lung cancer, cardio-respiratory diseases and possibly low birth weight (Dockery et al., 1993; Pope et al., 2002).

Egypt has suffered greatly from its air pollution. The most effectively reduce this pollution remains unanswered for Cairo and other mega cities in the developing countries. This study aims to assess air quality in Damietta harbor region. To achieve this objective the assessment of Air Pollutants for study area was based on; Implementing concentrations of $\mathrm{NO}_{2}$, $\mathrm{SO}_{2}, \mathrm{CO}, \mathrm{O}_{3}$ and $\mathrm{PM}_{10}$ emissions were measured continuously by ambient air quality monitoring analyzers station (AAQMS) in Damietta port area from January 2013 to December 2015.

\section{Methodology}

\subsection{Background of Study Area}

The Port is located on the northeastern coast of the Nile Delta, approx. $70 \mathrm{~km}$ west of Port Said, $250 \mathrm{~km}$ east of Alexandria. The Port of Damietta is strategically located on the international transport lane as well as for domestic supply to Egypt. The Damietta harbor was constructed in 1982 and is located about 9.7 $\mathrm{km}$ west of the Damietta Nile promontory with an area of approximately 11.8 million $\mathrm{m}^{2}$, of which 3.9 million $\mathrm{m}^{2}$ is water mass.

Damietta is a first class transshipment port, which can accommodate the new generation of large container vessels (> 6000 tons) due to the deep draft $(14.5 \mathrm{~m})$ and the modern stevedoring equipment at the port. In addition to this, vessels can enter and leave the port any time without restrictions, and vessels transiting the Suez Canal can use Damietta Port without any detours which can result in significant time savings.

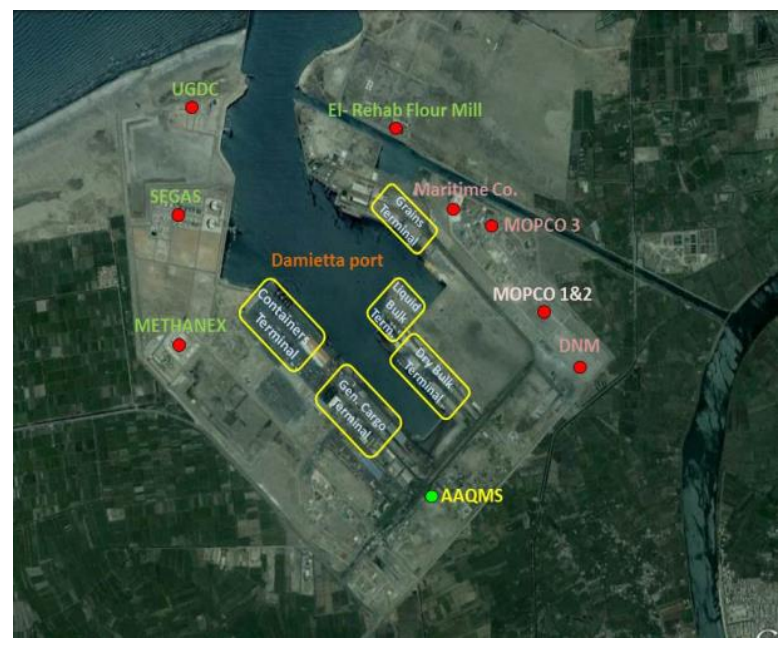

Figure (1): Damietta Port Area

\subsection{Activities in Damietta Port Area}

Damietta Port consists of several berths areas, such as; Containers, General Cargo, Dry Bulk, Liquid Bulk, and Grains Terminal Berths, and SEGAS (Spanish Egyptian Gas Company) Terminal, UGDC (United Gas Derivatives Company) and Petrochemicals Holding Company (ECHEM) and Methanex Cooperation, a Canadian Private Sector Company, is operating stand-alone methanol plants beside Damietta Port, adding to El Rehab Damietta Silos and Storage (Flour Mill).

\subsection{Ambient Air Quality Monitoring Station (AAQMS)}

Air pollutants $\left(\mathrm{NO}_{2}, \mathrm{SO}_{2}, \mathrm{O}_{3}, \mathrm{CO}\right.$, and $\mathrm{PM}_{10}$ ) and meteorological parameters (wind speed, wind direction, temperature, relative humidity and barometric pressure) had been monitored by using ambient air quality monitoring station (AAQMS) inside the territory of Damietta port. The concentrations of $\mathrm{NO}_{2}$, $\mathrm{SO}_{2}, \mathrm{O}_{3}$ and $\mathrm{PM}_{10}$ were expressed in $\mu \mathrm{g} / \mathrm{m}^{3}$, whereas $\mathrm{CO}$ was expressed in $\mathrm{mg} / \mathrm{m}^{3}$.

\section{Results and Discussion}

\subsection{Evaluation of Gases, $\mathrm{NO}_{2}, \mathrm{SO}_{2}, \mathrm{CO}$ and $\mathrm{O}_{3}$ in Ambient of Damietta Port Area:}

Concentrations of $\mathrm{NO}_{2}, \mathrm{SO}_{2}, \mathrm{CO}$ and $\mathrm{O}_{3}$ emissions were measured continuously by ambient air quality monitoring analyzers in 
Damietta port area in 2013, 2014 and 2015 respectively (Table 1).

Table (1): Annual Mean Concentrations of $\mathrm{NO}_{2}, \mathrm{SO}_{2}$, $\mathrm{CO}$ and $\mathrm{O}_{3}$ in 2013, 2014 and 2015

\begin{tabular}{l|l|l|l|l} 
Year & $\begin{array}{l}\mathbf{N O}_{2} \\
\left(\boldsymbol{\mu g} / \mathbf{m}^{\mathbf{3}}\right)\end{array}$ & $\begin{array}{l}\mathbf{S O}_{2} \\
\left(\boldsymbol{\mu g} / \mathbf{m}^{\mathbf{3}}\right)\end{array}$ & $\begin{array}{l}\mathbf{C O} \\
\left(\mathbf{m g} / \mathbf{m}^{\mathbf{3}}\right)\end{array}$ & $\begin{array}{l}\mathbf{O}_{\mathbf{3}} \\
\left(\boldsymbol{\mu g} / \mathbf{m}^{\mathbf{3}}\right)\end{array}$ \\
\hline $\mathbf{2 0 1 3}$ & 29.92 & 26.68 & 5.31 & 33.10 \\
$\mathbf{2 0 1 4}$ & 41.50 & 27.69 & 2.29 & 41.00 \\
$\mathbf{2 0 1 5}$ & 29.12 & 24.83 & 6.23 & 39.43
\end{tabular}

\subsubsection{Nitrogen Dioxide $\left(\mathrm{NO}_{2}\right)$}

The annual mean concentrations of $\mathrm{NO}_{2}$ in Damietta Port Area in 2013, 2014 and 2015 were $29.92,41.50$ and $29.12 \mu \mathrm{g} / \mathrm{m}^{3}$, respectively (Fig. 2), which did not exceed the AQL as stipulated in the Egyptian Environmental Law $4 / 94$ and its executive regulations $\left(80 \mu \mathrm{g} / \mathrm{m}^{3}\right)$.

It is observed from Fig. (3), the annual mean of $\mathrm{NO}_{2} \%$ in Damietta Port follow the order: $(41 \%)>(30 \%)>(29 \%)$ in 2014,2013 , 2015 year, respectively. High $\mathrm{NO}_{2}$ levels in year 2014 may be due to the high activities of shipping, goods transportation in the port area during this year.

The high level of Nitrogen dioxide concentrations in Damietta Port area were attributed to traffic (trucks and cars), operating cranes (as exhaust gas), shipping (hotelling and maneuvering) and partially may came from E-Methanex and MOPCO stacks. The results of this study were confirmed with previous researches (Mohamad et al., 2015; Podrez, 2015; Tenailleau et al., 2015).

\subsubsection{Sulfur Dioxide $\left(\mathrm{SO}_{2}\right)$}

The annual mean levels of $\mathrm{SO}_{2}$ in Damietta Port Area in 2013, 2014 and 2015 were 26.68, 27.69 and $24.83 \mu \mathrm{g} / \mathrm{m}^{3}$, respectively (Fig. 4), which did not exceed the AQL as stipulated in the Egyptian Environmental Law 4/94 and its executive regulations $\left(60 \mu \mathrm{g} / \mathrm{m}^{3}\right)$.

It is observed from Fig. (5), the annual mean of $\mathbf{S O}_{2} \%$ in Damietta Port follow the order: (35\%) $>(34 \%)>(31 \%)$ in 2014, 2013 and 2015, respectively.

Sulfur dioxide concentrations in Damietta Port area may be attributed to traffic (trucks and cars), operating cranes (as exhaust gas), shipping (hotelling and maneuvering) and partially may came from E-Methanex stacks. The results were confirmed with previous researches (Mohamad et al., 2015).

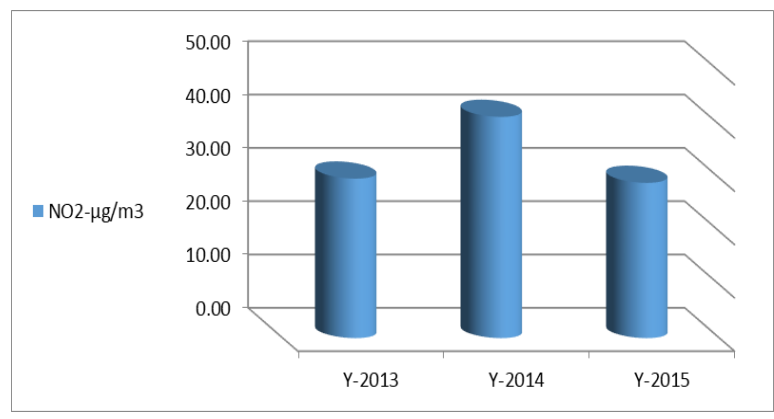

Figure (2): Annual Mean Concentrations of $\mathrm{NO}_{2}$ in Damietta Port Area (2013 - 2015).

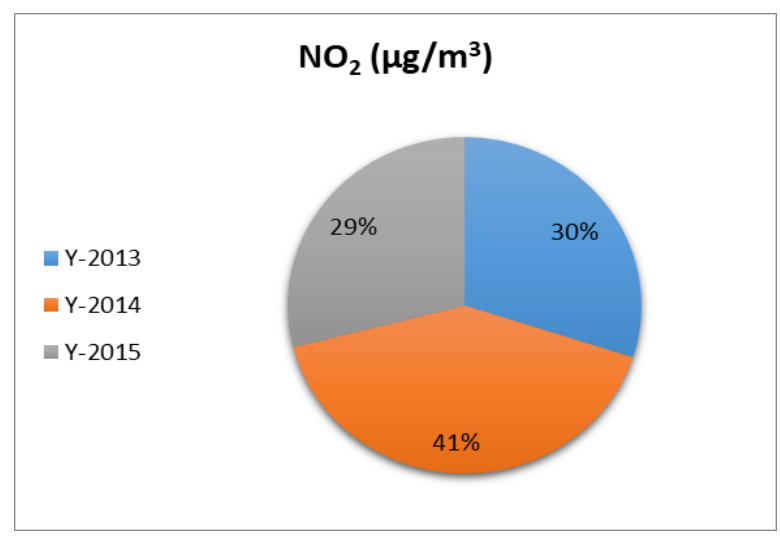

Figure (3): Annual Mean $\mathrm{NO}_{2} \%$ in Damietta Port Area (2013 - 2015).

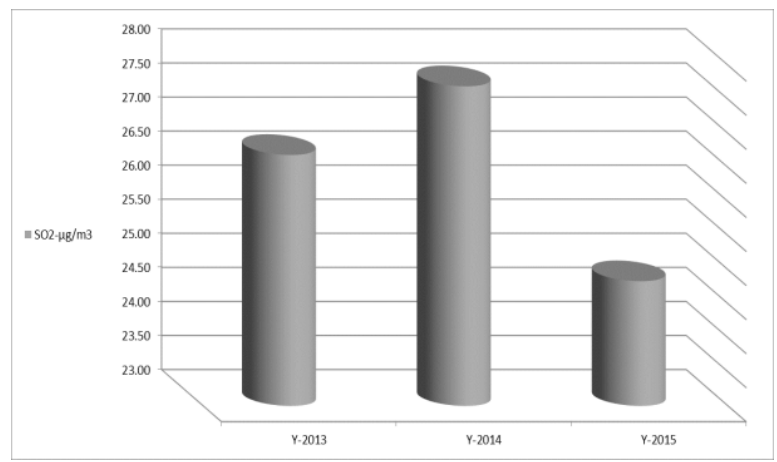

Figure (4): Annual Mean Concentrations of $\mathrm{SO}_{2}$ in Damietta Port Area (2013 - 2015).

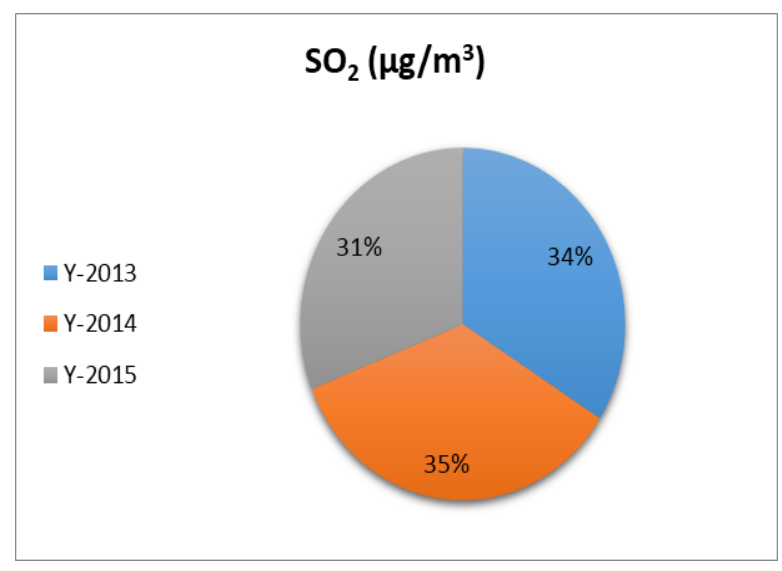

Figure (5): Annual Mean $\mathrm{SO}_{2} \%$ in Damietta Port Area (2013-2015). 


\subsubsection{Carbon Monoxide (CO)}

The annual mean levels of $\mathrm{CO}$ in Damietta Port Area in 2013, 2014 and 2015 were 5.31, 2.29 and $6.23 \mathrm{mg} / \mathrm{m}^{3}$, respectively (Fig. 6), which did not exceed the AQL as stipulated in the Egyptian Environmental Law 4/94 and its executive regulations $\left(10 \mathrm{mg} / \mathrm{m}^{3}\right.$ for $8 \mathrm{hrs}$.).

Carbon monoxide concentrations in Damietta Port area may be due to traffic trucks and cars, operating cranes as exhaust gas, shipping (hotelling and maneuvering) and partially may came from E-Methanex and MOPCO stacks. The results were confirmed with previous researches (Mohamad et al., 2015).

As shown in Fig. (7), the observed annual mean of CO \% in Damietta Port follow the order: $(45 \%)>(38 \%)>(17 \%)$ in 2015,2013 , and 2014 , respectively.

\subsubsection{Ozone $\left(\mathrm{O}_{3}\right)$}

The annual mean levels of $\mathrm{O}_{3}$ in Damietta Port Area in 2013, 2014 and 2015 were 33.10, 41.00 and $39.43 \mu \mathrm{g} / \mathrm{m}^{3}$, respectively (Fig. 8), which did not exceed the AQL as stipulated in the Egyptian Environmental Law 4/94 and its executive regulations $\left(120 \mu \mathrm{g} / \mathrm{m}^{3}\right.$ for $8 \mathrm{hrs}$.). Ozone concentrations in Damietta Port area were attributed to on-road-cars, trucks and buses. The results were confirmed with previous researches (Mohamad et. al, 2015).

As shown in Fig. (9), the annual mean of $\mathrm{O}_{3} \%$ in Damietta Port follow the order: (36\%) > $(35 \%)>(29 \%)$ in 2014, 2015 and 2013, respectively.

\subsection{Evaluation of PM10 in Ambient Emissions of Damietta Port Area}

Concentrations of $\mathrm{PM}_{10}$ emissions were measured continuously by ambient air quality monitor in Damietta port area. The annual mean levels of $\mathrm{PM}_{10}$ in Damietta Port Area in 2013, 2014 and 2015 were 83.56, 60.31 and $72.32 \mu \mathrm{g} / \mathrm{m}^{3}$ respectively, (Table 2 and Fig. 10), annual mean levels in 2013 and 2015 were higher than AQL as stipulated in the Egyptian Environmental Law 4/94 and its executive regulations $\left(70 \mu \mathrm{g} / \mathrm{m}^{3}\right)$.

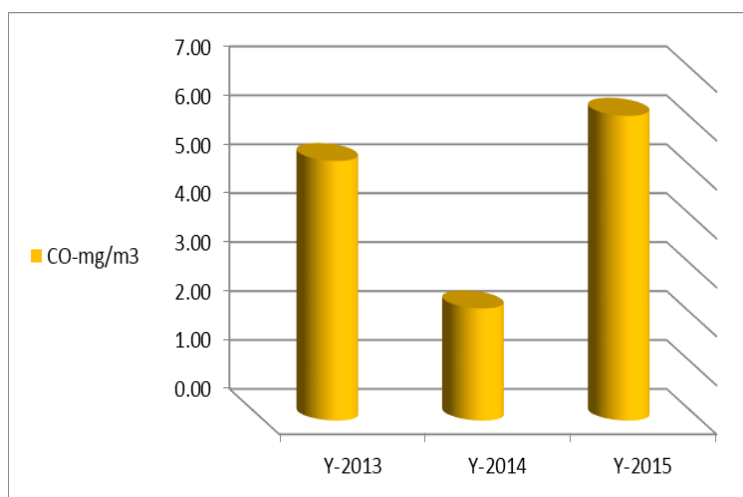

Figure (6): Annual Mean Concentrations of $\mathrm{CO}$ in Damietta Port Area (2013 - 2015).

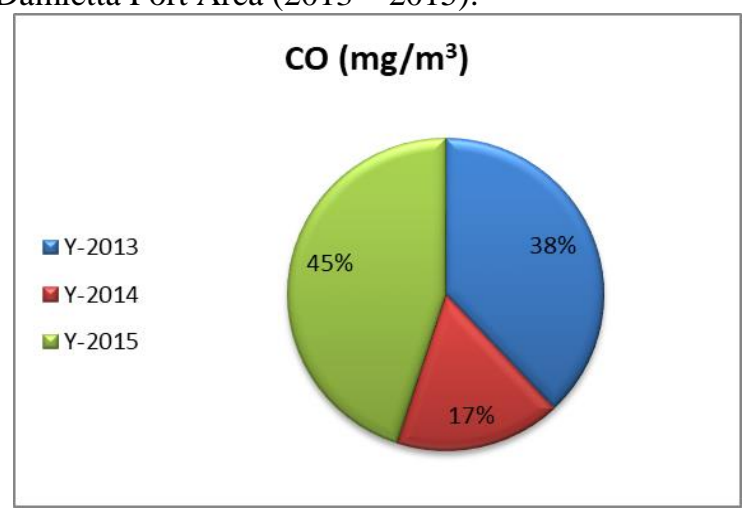

Figure (7): Annual Mean CO \% in Damietta Port Area (2013-2015).

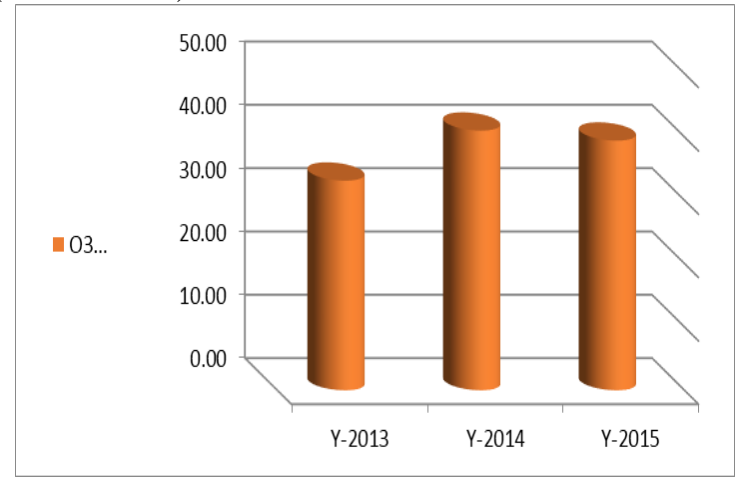

Figure (8): Annual Mean Concentrations of $\mathrm{O}_{3}$ in Damietta Port Area (2013 - 2015)

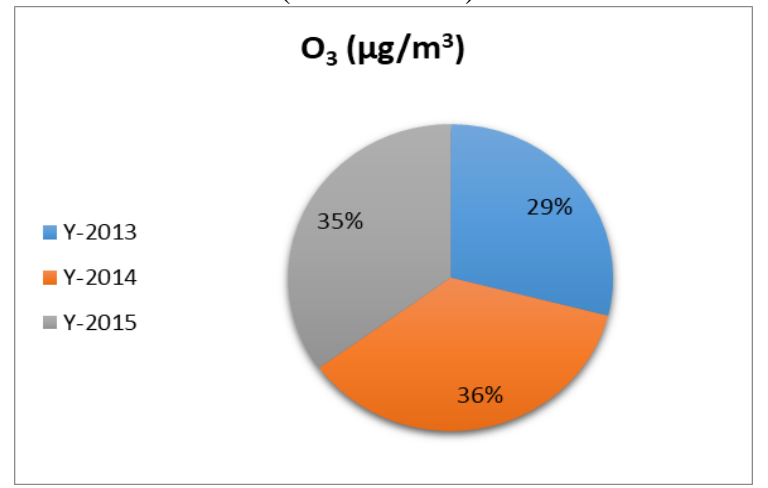

Figure (9): Annual Mean $\mathrm{O}_{3} \%$ in Damietta Port Area $(2013-2015)$ 
It is observed from Fig. (11), the annual mean of $\mathrm{PM}_{10} \%$ in Damietta Port follows the order: $(39 \%)>(33 \%)>(28 \%)$ in 2013,2015 , and 2014 year, respectively.

$\mathrm{PM}_{10}$ concentrations in Damietta Port area were attributed mainly to dust came from Dry Bulk Terminal Berths (handling of Fertilizers, Cement, Glass sand, ... etc), Grains Terminal Berths, movements of trucks on roads and partially may came from El-Rehab Flour Mill and MOPCO plant. The results were confirmed with previous researches (Mohamad et al., 2015).

Table (2): Annual Mean Concentrations of $\mathrm{PM}_{10}$ in 2013, 2014 and 2015.

\begin{tabular}{l|l} 
Year & PM $_{\mathbf{1 0}}\left(\boldsymbol{\mu g} / \mathbf{m}^{\mathbf{3}}\right)$ \\
\hline $\mathbf{2 0 1 3}$ & 83.56 \\
$\mathbf{2 0 1 4}$ & 60.31 \\
$\mathbf{2 0 1 5}$ & 72.32
\end{tabular}

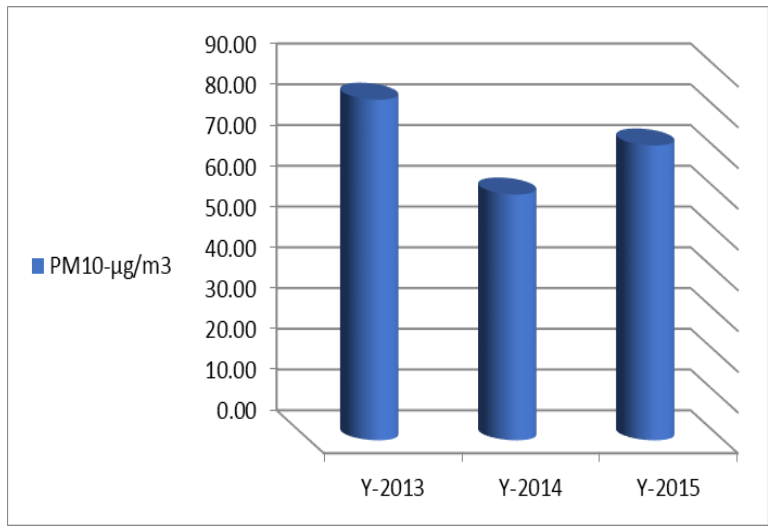

Figure (10): Annual Mean Concentrations of $\mathrm{PM}_{10}$ in Damietta Port Area (2013 - 2015).

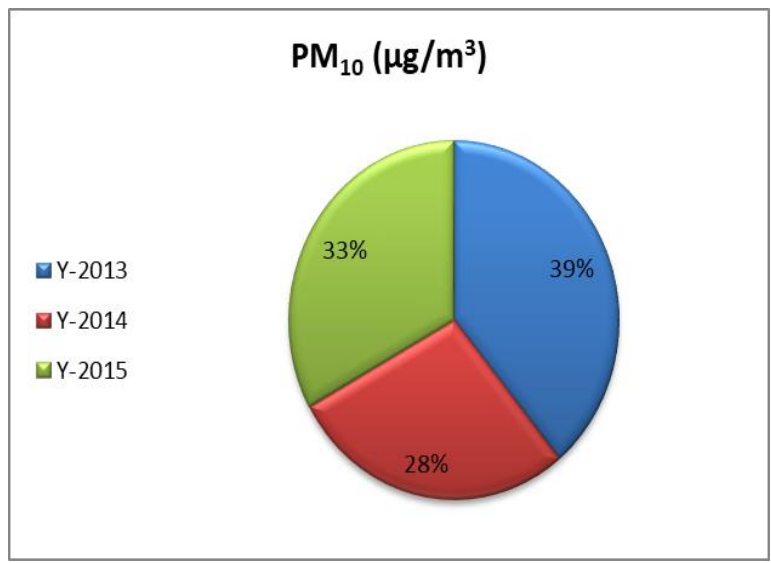

Figure (11): Annual Mean $\mathrm{PM}_{10} \%$ in Damietta Port Area $(2013$ - 2015).

\subsection{Comparison between annual mean concentrations of measured gases in Damietta Port $\left(\mathrm{NO}_{2}, \mathrm{SO}_{2}, \mathrm{CO}\right.$ and $\left.\mathrm{O}_{3}\right)$ in $2013-2015$.}

The annual mean concentration of measured gases in Damietta Port $\left(\mathrm{NO}_{2}, \mathrm{SO}_{2}, \mathrm{CO}\right.$ and $\mathrm{O}_{3}$ ) follows the order: $\mathrm{CO}>\mathrm{O}_{3}>\mathrm{NO}_{2}>\mathrm{SO}_{2}$ in 2013; $\mathrm{CO}>\mathrm{NO}_{2}>\mathrm{O}_{3}>\mathrm{SO}_{2}$ in 2014 and $\mathrm{CO}>$ $\mathrm{O}_{3}>\mathrm{NO}_{2}>\mathrm{SO}_{2}$ in 2015.

Air pollution due to ship emissions mainly concerns sulfur dioxide $\left(\mathrm{SO}_{2}\right)$, nitrogen dioxide $\left(\mathrm{NO}_{2}\right)$, and particulate matter. Besides that the European Union (EU) legislation enforces the use of a cleaner fuel in terms of sulfur content during ship hotelling longer than 2 $\mathrm{hr}$. Ships at berth are also still responsible for air pollution in the port areas, mainly because of the use of engines for supplying auxiliary devices (Adamo et al., 2014).

Recent studies show the contribution of ship emissions on fine and ultrafine particles (Healy et al., 2009; Donateo et al., 2014). Saxe and Larsen (2004) focused their study on three Danish ports, highlighting a considerable contribution to $\mathrm{NO}_{2}$ and $\mathrm{PM}_{10}$ air concentrations, posing health problems to people living or working near the harbors (Matthias et al., 2010).

\section{Conclusion}

The measured values for $\mathrm{NO}_{2}, \mathrm{SO}_{2}$ and $\mathrm{O}_{3}$ were well below the standard values provided by EEAA. Damietta City is located $8.5 \mathrm{~km}$ southeast of the existing Damietta Port. The prevailing wind is from the northwest which might provide moderate concentrations of $\mathrm{NO}_{2}$, $\mathrm{SO}_{2}$ and $\mathrm{O}_{3}$ in this locality that blow most of the emitting pollutes toward the land downwind.

The annual levels of $\mathrm{CO}$ were lower than $\mathrm{AQL}$ as recommended by EEAA. The levels of $\mathrm{PM}_{10}$ for most periods were higher than AQL as recommended by Egyptian Environmental lay $4 / 1994$

\section{References}

Adamo, F., G. Andria, G. Cavone, C. De Capua, A. Lanzolla, R. Morello, and M. Spadavecchia. 2014. Estimation of ship emissions in the port of Taranto. Measurement 14:982-988. 
Donateo, A., E. Gregoris, A. Gambaro, E. Merico, R. Giua, A. Nocioni, and D. Contini. 2014. Contribution of harbor activities and ship traffic to $\mathrm{PM}_{2.5}$, particle number concentrations and PAHs in a port city of the Mediterranean Sea (Italy). Environ. Sci. Pollut. Res. 21:9415-9429.

Dockery DW., Pope CA., Xu X, Spengler JD, Ware JH, Fay ME. 1993. An association between air pollution and mortality in six U.S. cities. The New England Journal of Medicine; 329 (24):17531759.

Healy, R.M., I.P. O’Connor, S. Hellebust, A. Allanic, J.R. Sodeau, and J.C. Wenger, 2009. Characterization of single particles from in-port ship emissions. Atmos. Environ. 43:6408-6414.

Matsumoto G. and Hanya T. (1980).Organic constituents in atmospheric fallout in the Tokyo area.Atmospheric Environ., 14:1409-1419.

Matthias, V., I. Bewersdorff, A. Aulinger, and M. Quante. 2010. The contribution of ship emissions to air pollution in the North Sea regions. Environ. Pollut. 158:2241-2250.

Mohamad ND., Ash'aaria ZH., Othman M. 2015. Preliminary assessment of air pollutant sources identification at selected monitoring stations in
Klang Valley, Malaysia. Procedia Environmental Sciences 30: 121 - 126.

Podrez M. (2015). An update to the ambient ratio method for 1-h $\mathrm{NO}_{2}$ air quality standards dispersion modeling. Atmospheric Environment 103: $163-170$.

Pope CA., Burnett RT, Thun MJ, Calle EE, Krewski D, Ito K. 2002. Lung Cancer, Cardiopulmonary Mortality and Long-Term Exposure to Fine Particulate Air Pollution. J Amer Med Assoc.; 287(9):1132-1141.

Saxe, H., and T. Larsen. 2004. Air pollution from ships in three Danish ports. Atmos. Environ. 38:4057-4067. doi:10.1016/j.atmosenv.2004.03.055

Schembari, C., F. Cavalli, E. Cuccia, J. Hjorth, G. Calzolai, N. Pérez, J. Pey, P. Prati, and F. Raes. 2012. Impact of a European directive on ship emissions on air quality in Mediterranean harbors. Atmos. Environ. 61:661-669.

Tenailleau QM., Mauny F., Joly D., François S., Bernard N. 2015. Air pollution in moderately polluted urban areas: How does the definition of "neighborhood" impact exposure assessment? Environmental Pollution 206: 437-448

عنوان البحث: تقييم جودة الهواء فى منطقة ميناء دمياط ملّي إبر اهيم الجمال'، علية عبد الثكور عليخ، محمود سالم إبراهيم'، امنية عبد السلام البطراوى'، وليد عبد الكريم

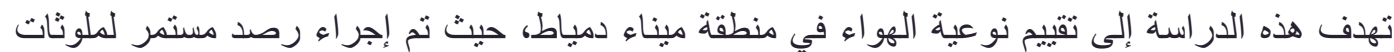

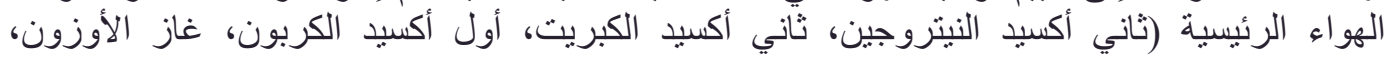

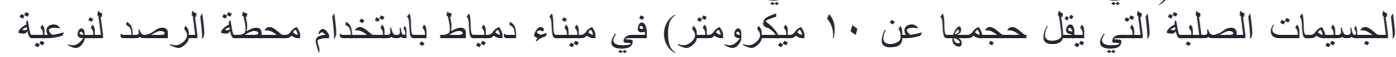

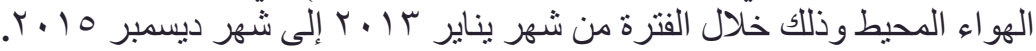

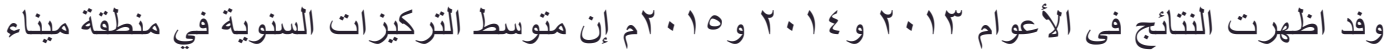

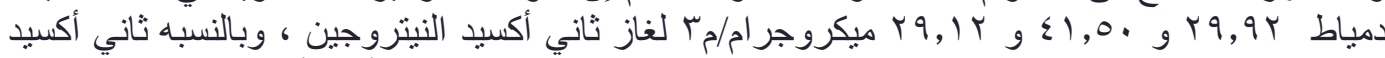

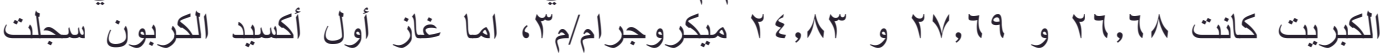

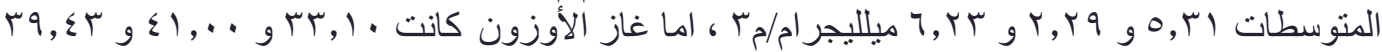

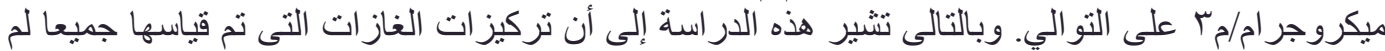

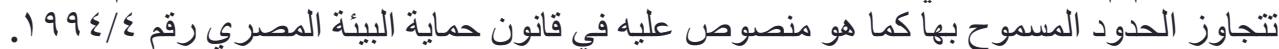

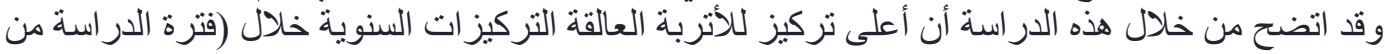

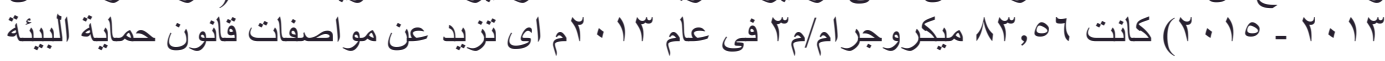

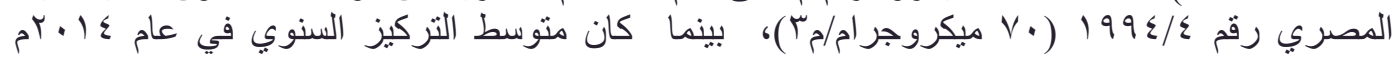

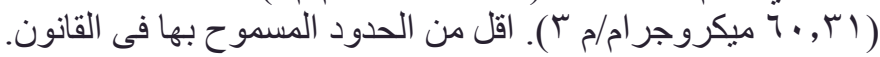

